\title{
Response to oral administration of pteroylmonoglutamic acid or pteroylpolyglutamate in newborn infants of low birth weight*
}

\author{
By PAMELA D. SAMUEL † AND W. L. BURLAND †† \\ The Clinical Investigation Unit, Glaxo Laboratories, Greenford, Middlesex \\ AND K. SIMPSON \\ Paediatric Department, Leicester General Hospital, Leicester
}

(Received 26 June 1972-Accepted I 5 February 1973)

\begin{abstract}
I. Newborn infants of low birth weight absorb both pteroylmonoglutamic acid and pteroylpolyglutamate.

2. There was a significant fall in serum folate concentrations during the first $\mathrm{I}_{4} \mathrm{~d}$ of life in these infants, but a daily supplement of $50 \mu \mathrm{g}$ pteroylmonoglutamic acid or pteroylpolyglutamate was sufficient to prevent the development of subnormal serum folate concentrations.
\end{abstract}

It is well known that a fall in serum and red cell folate concentration occurs in early infancy, the fall being most rapid and profound in infants of low birth weight and gestationally immature infants (Matoth, Pinkas, Zamir, Mooallem \& Grossowicz, I964; Shojania \& Gross, I964; Matoth, Pinkas \& Sroka, ı965; Strelling, Blackledge, Goodall \& Walker, I966; Vanier \& Tyas, 1967; Roberts, Arrowsmith, Rau \& MonkJones, I969). The development of low blood folate concentrations in these infants can be prevented by the intramuscular injection of $100 \mu \mathrm{g}$ pteroylmonoglutamic acid on alternate days for the first 4 weeks of life (Burland, Simpson \& Lord, 1971).

The dietary folate requirements of full-term newborn infants have been said to be from 20 to $50 \mu \mathrm{g} / \mathrm{d}$ (Matoth et al. I964; Sullivan, Luhby \& Streiff, I966). Vanier \& Tyas (1967) suggested that pre-term infants require more. Ford \& Scott ( I968) found that human and cow's milk contain approximately $50 \mathrm{ng}$ total folate/ml. Ford \& Scott (1968) and Burland et al. (1971) found the total folate content of proprietary milks prepared for infant feeding in the United Kingdom to be from 30 to $70 \mathrm{ng} / \mathrm{ml}$, but on heating some of this folate may be destroyed. Burland et al. (1971) calculated that infants of low birth weight were likely to receive less than $15 \mu \mathrm{g}$ folate/d from their diet at I weck of age.

Though most of the folate in milk is in the free monoglutamate form, some is present as pteroylpolyglutamate. It was decided to investigate the ability of newborn infants of low birth weight to absorb pteroylmonoglutamic acid and pteroylpolyglutamate. In addition, we have attempted to determine the amount of orally administered folate necessary to prevent very low blood folate concentrations developing in these infants.

* A preliminary account of this work has been published in Proc. Nutr. Soc. (1973), 32, 4 A.

$\uparrow$ Present address: Servier Research Institute, Harrow, Middlesex.

\$ For reprints. 
Table I. Gestational ages, sexes and birth weights of newborn infants completing the study (serum folaie assays)

\begin{tabular}{|c|c|c|c|}
\hline Group & $\begin{array}{l}\text { Gestational age (range } \\
\text { and mean, weeks) }\end{array}$ & $\overbrace{\delta}^{\operatorname{Sex}}$ & $\begin{array}{l}\text { Birth weights }(\mathrm{g}) \\
\text { (range and mean) }\end{array}$ \\
\hline Untreated & $33^{-36}(34)$ & 2 & $1484-2222(1891)$ \\
\hline Pteroylmonoglutamic acid supplement & $30-37(34)$ & 8 & I335-2052 ( 670$)$ \\
\hline Pteroylpolyglutamate supplement & $29-38(35)$ & 5 & $1335-2130(1742)$ \\
\hline
\end{tabular}

\section{EXPERIMENTAL}

Forty-five healthy infants weighing less than $2 \cdot 5 \mathrm{~kg}$ at birth were entered consecutively into one of three groups. One group received a supplement of $50 \mu \mathrm{g}$ pteroylmonoglutamic acid in solution daily by mouth, another $5^{\circ} \mu \mathrm{g}$ pteroylpolyglutamates in solution and the third remained untreated. The supplement was given with the early evening feed on each of the first i $4 \mathrm{~d}$ of life. All the infants received the same milk food prepared from a commercially available evaporated milk. Blood samples were taken for serum and red cell folate assay on the ist day before the first feed and again $14 \mathrm{~d}$ later, as an indication of the absorption of the administered folate.

Pteroylpolyglutamates were prepared according to the method of Perty \& Chanarin (I968). The folate content of the pteroylpolyglutamates was assayed by the method of Hoffbrand \& Peters ( I 669 ). Scrum folate was determined according to the method described by Waters \& Mollin ( $196 \mathrm{I}$ ) and red cell folate concentrations by the method of Hoffbrand, Newcombe \& Mollin (1966). Estimation of the folate content of the milk given to all the infants in the trial was made by the method of Butterworth, Santini \& Frommeyer (1963).

\section{RESULTS}

The gestational age, sex and birth weights of the thirty-six infants who completed the study are shown in Table $\mathrm{I}$. Some infants failed to complete the study because of intercurrent illness involving additional treatment during the course of the investigation or because of our inability to obtain adequate volumes of blood for serum folate assays at $\mathrm{i} 4 \mathrm{~d}$. Insufficient blood was available to determine red cell folate concentrations at $14 \mathrm{~d}$ in some infants included in the final analysis.

\section{Serum and red cell folate concentrations}

The serum and red cell folate concentrations on days $I$ and I4 in each of the three groups of infants are shown in Fig. $I$ and Table 2. The concentrations of serum and red cell folate on day I did not differ significantly between the three groups (Student's $t$ test). There appeared to be no relationship between the folate concentrations and whether or not the mother had received pteroylmonoglutamic acid during pregnancy. Nor did there appear to be a relationship with birth weight or gestational age.

Serum folate concentrations fell significantly in all three groups by day $\mathrm{I}_{4}$. The fall was most significant in the untreated group; three of nine infants had a concentration less than $6 \mathrm{ng} / \mathrm{ml}$ at $\mathrm{I} 4 \mathrm{~d}$ - that is, below the normal range for the method of assay 


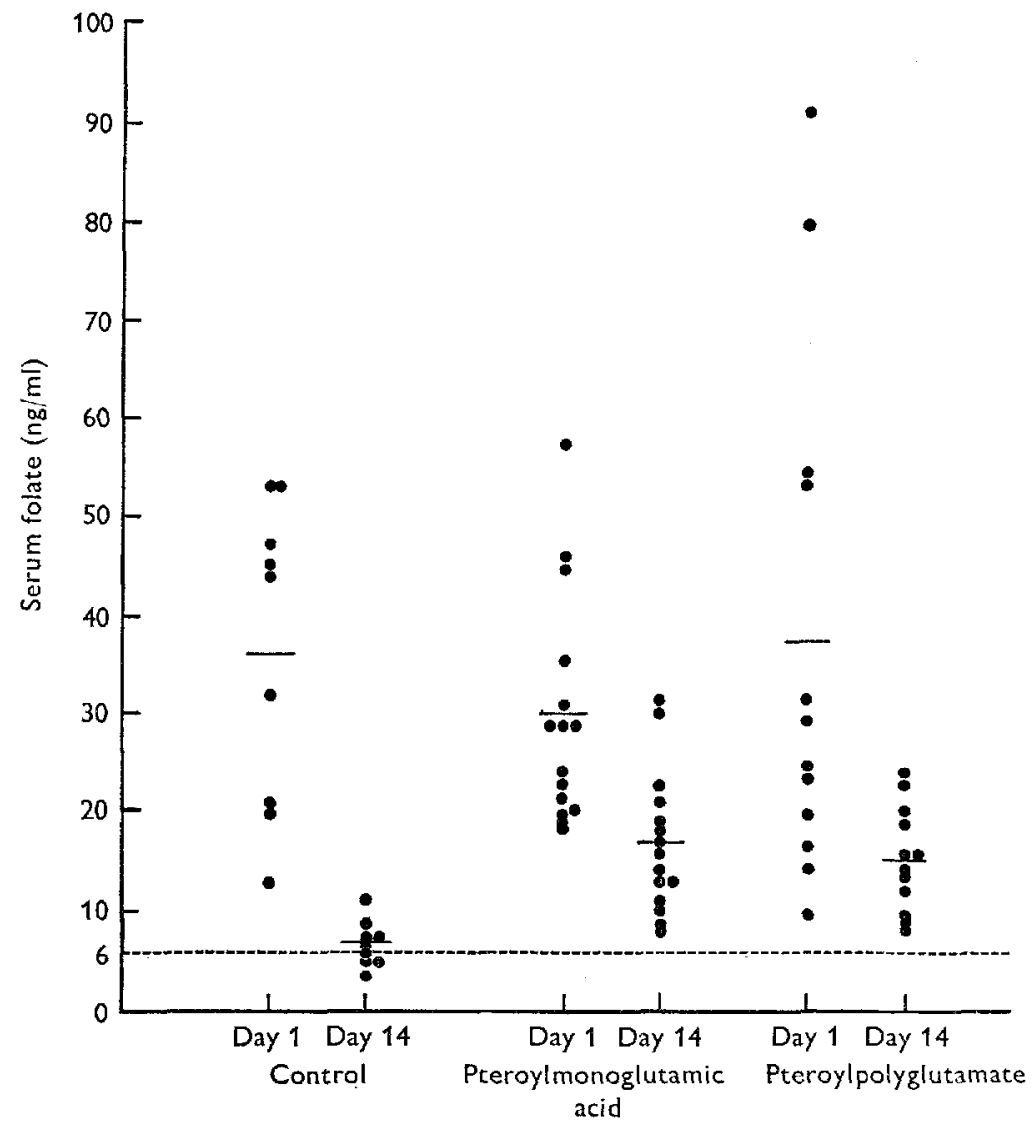

Fig. I. Serum folate concentration at 1 and ${ }_{14} \mathrm{~d}$ of age in three groups of infants of low birth weight, untreated or treated orally with a daily supplement of $50 \mu \mathrm{g}$ pteroylmonoglutamic acid or pteroylpolyglutamate. Bar denotes the mean; $6 \mathrm{ng} / \mathrm{ml}$ denotes the lowest limit of the normal range of serum folate concentrations for the method of assay.

Tablc 2. Serum and red cell folate concentrations at I and ${ }_{14} d$ of age in three groups of infants of low birth weight, untreated or given orally a daily supplement of $50 \mu \mathrm{g}$ pteroylmonoglutamic acid or pteroylpolyglutamate

(Mean values with their standard errors; number of infants in parentheses)

\begin{tabular}{|c|c|c|c|c|c|c|}
\hline \multirow[b]{2}{*}{ Day } & \multicolumn{3}{|c|}{ Serum folate $(\mathrm{ng} / \mathrm{ml})$} & \multicolumn{3}{|c|}{ Red cell folate $(\mathrm{ng} / \mathrm{ml})$} \\
\hline & $\begin{array}{l}\text { Untreated } \\
\text { (9) }\end{array}$ & $\begin{array}{l}\text { Pteroylmono- } \\
\text { glutamic acid } \\
\text { (15) }\end{array}$ & $\begin{array}{l}\text { Pteroylpoly- } \\
\text { glutamate } \\
\text { (12) }\end{array}$ & $\begin{array}{l}\text { Untreated } \\
\text { (9) }\end{array}$ & $\begin{array}{l}\text { Pteroylmono- } \\
\text { glutamic acid } \\
\text { (10) }\end{array}$ & $\begin{array}{l}\text { Pteroylpoly- } \\
\text { glutamate } \\
\text { (4) }\end{array}$ \\
\hline $\mathbf{I}$ & $36 \cdot 4 \pm 5 \cdot 1$ & $30 \cdot 0 \pm 3 \cdot 0$ & $37 \cdot 7 \pm 7 \cdot 7$ & $615 \pm 38$ & $525 \pm 86$ & $596 \pm 62$ \\
\hline 14 & $6.6 \pm 0.7$ & $16 \cdot 9 \pm I \cdot 8$ & $15.5 \pm 1 \cdot 6$ & $472 \pm 52$ & $449 \pm 24$ & $445 \pm 59$ \\
\hline \multicolumn{7}{|c|}{ Significance between values at days $\mathrm{I}$ and $\mathrm{I} 4$} \\
\hline & $P<0.001$ & $P<0.01$ & $P<0.02$ & NS & NS & NS \\
\hline
\end{tabular}


Table 3. Serum folate concentrations on day $\mathrm{I}_{4}$, expressed as ratios of the values on day $\mathrm{I}$, in three groups of infants of low birth weight, untreated or given orally a daily supplement of $50 \mu \mathrm{g}$ of pteroylmonoglutamic acid or pteroylpolyglutamate

\begin{tabular}{|c|c|c|c|}
\hline \multirow{3}{*}{ Serum folate $(\mathrm{ng} / \mathrm{ml})$} & Untrented & Pteroylmonoglutamic acid & Pteroylpolyglutamate \\
\hline & $0.214 \pm 0.13 \mathrm{I}$ & $\begin{array}{c}0.589 \pm 0.216 \\
(15)\end{array}$ & $\begin{array}{c}0.54 \mathrm{I} \pm 0.24 \\
(\mathrm{I} 2)\end{array}$ \\
\hline & & $P<0.001$ & $P<0.01$ \\
\hline \multirow[t]{2}{*}{ Red cell folate $(\mathrm{ng} / \mathrm{ml})$} & $\begin{array}{c}0.759 \pm 0.165 \\
(9)\end{array}$ & $\begin{array}{c}0.797 \pm 0.436 \\
\text { (10) }\end{array}$ & $0.745 \pm \frac{(4)}{14}(81$ \\
\hline & & NS & NS \\
\hline
\end{tabular}

(Waters \& Mollin, I96I). Serum folate in one infant was less than $4 \mathrm{ng} / \mathrm{ml}$; at this concentration there is believed to be a greatly increased risk of ensuing megaloblastic anaemia. There was no significant fall in red cell folate in any group.

Table 3 compares the rate of fall of serum and red cell folate in the three groups of infants. There was a significant difference in the rate of fall of serum folate between the treated groups and the untreated group but no difference between the two groups who received treatment. There was no difference in the rate of change in red cell folate when the groups were compared with each other.

\section{Milk folate concentrations}

The total folate activity of the evaporated milk given to the infants throughout the investigation was $49 \mathrm{ng} / \mathrm{ml}$ and the free folate activity was $42 \mathrm{ng} / \mathrm{ml}$. At $\mathrm{I} 4 \mathrm{~d}$, an infant weighing $2 \mathrm{~kg}$ at birth might therefore be expected to receive $I 9 \mu \mathrm{g} / \mathrm{d}$ of folate from milk, of which $16 \mu \mathrm{g}$ were in the free monoglutamate form.

\section{DISCUSSION}

The values obtained for serum folate in the groups of infants indicate that pteroylpolyglutamate is absorbed in the newborn infant of low birth weight. This suggests that these infants do not lack jejunal pteroylpolyglutamate hydrolase, the enzyme thought to be involved in the absorption of dietary pteroylpolyglutamate.

The considerable fall in serum folate concentrations in untreated infants during the first $14 \mathrm{~d}$ of life was confirmed. The administration of $50 \mu \mathrm{g}$ pteroylmonoglutamic acid or pteroylpolyglutamate did not prevent a fall occurring but resulted in significantly higher concentration of folate in the serum at $\mathrm{I} 4 \mathrm{~d}$. All but one of the untreated infants had serum folate concentrations at or below the concentrations found in treated infants $(8 \mathrm{ng} / \mathrm{ml})$.

A fall in red cell folate concentration can only be expected after a considerably longer 
period of exposure to low serum folate concentrations than was experienced in this study.

The recommended daily requirement for normal infants up to the age of 6 months is $40 \mu \mathrm{g}$ pteroylmonoglutamic acid (WHO, 1970 ). Our findings suggest that an oral supplement of $50 \mu \mathrm{g}$ folate daily is sufficient to prevent infants of low birth weight developing subnormal blood folate concentrations.

\section{Conclusions}

Newborn infants of low birth weight are able to absorb both monoglutamate and polyglutamate forms of folate, however, these infants have a requirement for folate in excess of the amount they are likely to receive in their diet. Since blood folate concentrations remain low for at least 3 months in such infants, it may be justified to advise giving a $50 \mu \mathrm{g}$ daily supplement of pteroylmonoglutamic acid. Alternatively, milks intended for infant feeding could be fortified so that they ensure a total folate intake of at least $70 \mu \mathrm{g}$ daily.

The authors thank the nursing staff and junior hospital staff from the Special Care Baby Unit, Leicester General Hospital, for their valuable assistance. Mr J. O. Morgan in the Department of Haematology, Royal Postgraduate Medical School, London, performed the assays.

\section{REFERENCES}

Burland, W. L., Simpson, K. \& Lord, J. (1971). Archs Dis. Childh. 46, 189.

Butterworth, C. E. Jr, Santini, R. Jr \& Frommeyer, W. B. Jr (1963). J. clin. Invest. 42, I929.

Ford, J. E. \& Scott, K. J. (1968). F. Dairy Res. 35, 85 .

Hoffbrand, A. V., Newcombe, B. F. \& Mollin, D. L. (1966). F. clin. Path. 19, 17.

Hoffbrand, A. V. \& Peters, T. J. (1969). Biochim. biophys. Acta 192, 479.

Matoth, Y., Pinkas, A. \& Sroka, C. (1965). Israel Y. med. Sci. r, 730.

Matoth, Y., Pinkas, A., Zamir, R., Mooallem, F. \& Grossowicz, N. (1964). Pediatrics, Springfield 33, 507.

Perry, J. \& Chanarin, I. (1968). Br. med. $\mathscr{~} 4,546$.

Roberts, P. M., Arrowsmith, D. E., Rau, S. M. \& Monk-Jones, M. E. (r969). Archs Dis. Childh. 44, 637.

Shojania, A. M. \& Gross, S. (1964). F. Pediat. 64, 323.

Strelling, M. K., Blackledge, G. D., Goodall, H. B. \& Walker, C. H. M. (I966). Lancet i, 898.

Sullivan, L. W., Luhby, A. L. \& Streiff, R. R. (I966). Am. F. clin. Nutr. I8, 3 г I.

Vanier, T. M. \& Tyas, J. F. (1967). Archs Dis. Childh. 42, 57.

Waters, A. H. \& Mollin, D. L. (1961). F. clin. Path. 14, 335.

WHO (1970). Tech. Rep. Ser. Wld Hlth Org. no. 452. 